\title{
Development and validation of HPLC method for analysis of dexamethasone acetate in microemulsions
}

\author{
Maria Cristina Cocenza Urban', Rubiana Mara Mainardes ${ }^{2}$, Maria Palmira Daflon Gremião ${ }^{1 *}$
}

\author{
${ }^{1}$ Departamento de Fármacos e Medicamentos, Faculdade de Ciências Farmacêuticas de Araraquara, Universidade Estadual \\ Paulista "Júlio de Mesquita Filho”, '2 Departamento de Farmácia, Universidade Estadual do Centro-Oeste
}

\begin{abstract}
A simple, rapid, accurate and sensitive method was developed for quantitative analysis of dexamethasone acetate in microemulsions using high performance liquid chromatography (HPLC) with UV detection. The chromatography parameters were stainless steel Lichrospher 100 RP-18 column ( $250 \mathrm{~mm}$ x 4 mm i.d., 5 $\mu \mathrm{m}$ particle size $)$, at $30 \pm 2{ }^{\circ} \mathrm{C}$. The isocratic mobile phase was methanol:water $(65: 35 ; \mathrm{v} / \mathrm{v})$ at a flow rate of at $1.0 \mathrm{~mL} \cdot \mathrm{min}^{-1}$. The determinations were performed using UV-Vis detector set at $239 \mathrm{~nm}$. Samples were prepared with methanol and the volume injected was $20 \mu \mathrm{L}$. The analytical curve was linear $\left(\mathrm{r}^{2} 0.9995\right)$ over a wide concentration range $\left(2.0-30.0 \mu \mathrm{g} \cdot \mathrm{mL}^{-1}\right)$. The presence of components of the microemulsion did not interfere in the results of the analysis. The method showed adequate precision, with a relative standard deviation (RSD) smaller than 3\%. The accuracy was analyzed by adding a standard drug and good recovery values were obtained for all drug concentrations used. The HPLC method developed in this study showed specificity and selectivity with linearity in the working range and good precision and accuracy, making it very suitable for quantification of dexamethasone in microemulsions. The analytical procedure is reliable and offers advantages in terms of speed and low cost of reagents.
\end{abstract}

Uniterms: Dexamethasone acetate/determination. Microemulsions/quantitative analysis. High performance liquid chromatography/quantitative analysis. Analytical method/validation.

Um método simples, rápido, preciso e sensível foi desenvolvido para a análise quantitativa de acetato de dexametasona em microemulsões usando cromatografia líquida de alta eficiência (CLAE). Os parâmetros cromatográficos foram: coluna cromatográfica Lichrospher $100 \mathrm{RP}-18$, $(250 \mathrm{~mm} \times 4 \mathrm{~mm}$ i.d., $5 \mu \mathrm{m}$ partícula tamanho), com temperatura de coluna de $30 \pm 2{ }^{\circ} \mathrm{C}$. A fase móvel foi composta de metanol: água $(65: 35 ; \mathrm{v} / \mathrm{v})$ com fluxo isocrático de $1 \mathrm{~mL} \cdot \mathrm{min}^{-1}$ e volume de injeção de $20 \mu \mathrm{L}$. As determinações foram realizadas utilizando detector UV-Vis no comprimento de onda de $239 \mathrm{~nm}$. A curva analítica mostrou-se linear $\left(\mathrm{r}^{2} 0,999\right)$ em uma ampla faixa de concentração $\left(2,0-30,0 \mu \mathrm{g} \cdot \mathrm{mL}^{-1}\right)$. A presença de componentes da microemulsão não interferiu nos resultados da análise. O método mostrou precisão adequada, com desvio padrão relativo menor que 3\%. A exatidão foi analisada pela adição de padrões do fármaco e valores de recuperação dentro dos limites recomendáveis foram obtidos para todas as concentrações estudadas. O método por CLAE mostrou especificidade e seletividade com linearidade dentro da faixa de concentração utilizada e precisão e exatidão que tornam o método adequado para a análise de dexametasona em microemulsões. O procedimento analítico é fidedigno e oferece vantagens em termos de velocidade e custo de reativos.

Unitermos: Acetato de dexametasona/determinação. Microemulsões/análise quantitativa. Cromatografia líquida de alta eficiência/análise quantitativa. Método de análise/validação.

\section{INTRODUCTION}

Since 1948, with the introduction of cortisone and

\footnotetext{
*Correspondence: M.P.D. Gremião. Departamento de Fármacos e Medicamentos, Faculdade de Ciências Farmacêuticas. Universidade Estadual PaulistaUNESP, Rod. Araraquara-Jaú km 1 - 14801-902 - Araraquara - SP, Brasil. E-mail: pgremiao@fcfar.unesp.br
}

later hydrocortisone (1951), anti-inflammatory steroids have become a prominent pharmacological class. They are currently the drugs of choice for the treatment of several diseases, despite their adverse side effects (Avery, Woolfrey, 1997).

The use of topical steroid preparations represented a major advance in dermatology. Dexamethasone ace- 
tate (9-fluoro-11 $\beta-17,21$-trioxy-16 $\alpha$-methylpregna-1,4diene-3,20-dione 21-acetate monohydrate) is a steroid indicated for the treatment of several pathologies due to its anti-inflammatory and inmunosuppresor effects (Figure 1). This steroid is frequently incorporated in ointments, creams, lotions, aerosols and microemulsions (Gasco et al., 1988; Hashigushi et al., 1997; Vianna et al., 1998; Lehmann et al., 2001).

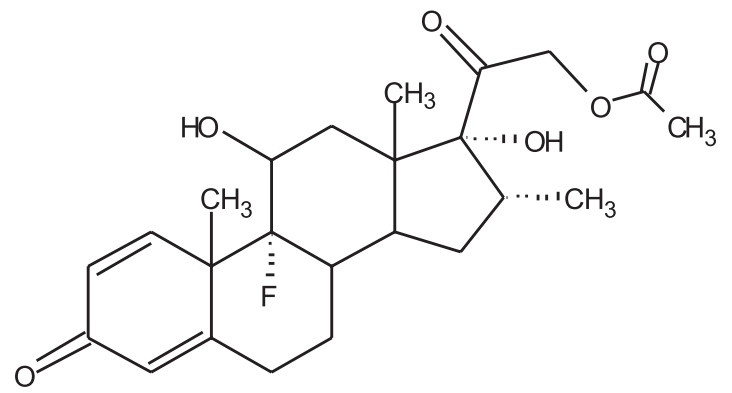

FIGURE 1 - Chemical structure of dexamethasone acetate.

Microemulsions are isotropic and thermodynamically stable solutions, generally composed of a combination of three to five components: oil, water, surfactant, cosurfactant and active substance (Constantinides, Scalart, 1997). The microemulsions show great potential as drug delivery systems because they can improve the solubility, absorption and therapeutic efficacy of the drug (Formariz et al., 2005).

Surfactants are extensively used to stabilize drug delivery systems. Commonly they are molecules selfassembled in water or in oil, leading to the formation of a well defined microstructure. Even a single surfactant can display a rich variety of structures that depends on several parameters, such as water content and temperature. Nevertheless, these microheterogeneous systems can interfere with drug separation and detection, and an adequate analytical method is needed to analyze the drug carried by these systems.

Capillary electrophoresis has been used to determine of dexamethasone (Guo et al., 2004) in pharmaceutical dosage forms. Thin-layer chromatographic-densitometric method is also described for the analysis of dexamethasone in an ointment (Krzek et al., 2005). Another method for analysis of dexamethasone acetate in ointments reported is flow-injection chemiluminescence (Wu, Lv, 2007). Although these methods are versatile tools in pharmaceutical analysis, they are time-consuming. HPLC remains the analytical method of choice, especially for analysis for topical formulations, owing to their complex composition. Few HPLC methods are described on the literature for the analysis of dexamethasone acetate in creams and ointments (Capella-Peiró, 2002, Garcia et al., 2003) and in other pharmaceutical forms (Vianna et al., 1998; Milojevic et al., 2002). HPLC is very useful for analysis of complex samples, such as ointments and creams, as it provides drug separation, determination and the elimination of most interference problems (Willians et al., 1981). However, no HPLC method for the analysis of the dexamethasone in microemulsion has been described.

The validation of an analytical method must demonstrate that it fulfills all the requirements of the analytical applications, ensuring the reliability of the results. For this reason, the tests must show that its specificity, linearity, precision, sensitivity, accuracy and limit of quantification are adequate for the analysis (ICH, 2003; British Pharmacopoeia, 2001; ANVISA, 2003; USP, 2004).

The aim of this study was to develop a simple, rapid, specific, precise and accurate reversed-phase HPLC method for the determination of dexamethasone acetate in microemulsions. The parameters used to validate the method were linearity, specificity, precision, accuracy and limit of quantification.

\section{MATERIAL AND METHODS}

\section{Materials}

Dexamethasone acetate (Purifarma, São Paulo, Brazil) (99\%) was used without further purification. The microemulsion was composed of isopropyl myristate (Henrifarma, São Paulo, Brazil) as the oily phase, PPG-5 Ceteth-20 (Croda, São Paulo, Brazil) as surfactant and distilled water.

The drug-containing microemulsions and the solutions were stable throughout the experiments and remained stable for a further six months.

Methanol (HPLC grade - Mallinckrodt, USA) was used to prepare the mobile phase and to dilute the samples. Water was obtained by distillation.

\section{Methods}

\section{Instrumentation and chromatographic conditions}

The method was performed on a Shimadzu System consisting of: Solvent Delivery Module LC-9A, Ultraviolet-Visible Spectrophotometric Detector Module SPD-6AV, Column Oven Module CTO-6A and System Controller Module SCL-6B with a Rheodyne injection valve with a $20 \mu \mathrm{L}$ loop attached.

Isocratic Chromatographic separations were carried out in a stainless steel Merck Lichrospher 100 RP-18 colu- 
$\mathrm{mn}(250 \mathrm{~mm} \times 4 \mathrm{~mm}$ i.d., $5 \mu \mathrm{m}$ particle size $)$ at $30^{\circ} \mathrm{C}$, with a methanol-water $(65: 35 \mathrm{v} / \mathrm{v})$ mobile phase and flow-rate of $1.0 \mathrm{~mL} \cdot \mathrm{min}^{-1}$. The mobile phase was filtered through a $0.45 \mu \mathrm{m}$ Millipore membrane filter and degassed with helium for $15 \mathrm{~min}$ before use. The determinations were performed with UV-Vis detector set at $239 \mathrm{~nm}$. The sensitivity was 0.08 AUFS and the chart speed $2.5 \mathrm{~mm} \cdot \mathrm{min}^{-1}$.

\section{Dexamethasone acetate standard - analytical curve}

The methanolic dexamethasone acetate standard solution $\left(1 \mathrm{mg} \cdot \mathrm{mL}^{-1}\right)$ was freshly prepared by transferring 10 $\mathrm{mg}$ of dexamethasone acetate standard, accurately weighed, to a $10 \mathrm{~mL}$ volumetric flask, using methanol to transfer the sample and to complete the volume. A $2.5 \mathrm{~mL}$ aliquot of this primary solution was volumetrically transferred to a $25 \mathrm{~mL}$ volumetric flask and methanol added to make up the volume, giving a $100 \mu \mathrm{g} \cdot \mathrm{mL}^{-1}$ stock solution. Working solutions, in a concentration range of 2.0 - $30.0 \mu \mathrm{g} \cdot \mathrm{mL}^{-1}$, were prepared by diluting the stock solution in methanol. To obtain the analytical curve, $20 \mu \mathrm{L}$ of each concentration was injected into the HPLC system and the area under curve (AUC) for each peak was plotted versus dexamethasone concentration. The analyses were carried out in triplicate and a straight line standard curve was obtained by linear regression of the experimental data.

\section{Microemulsion preparation}

All components, isopropyl myristate, PPG-5 Ceteth-20 and distilled water, were accurately weighed and heated to temperatures between 50 and $60^{\circ} \mathrm{C}$, with magnetic stirring to ensure complete mixing.

\section{Incorporation of dexamethasone acetate into microemulsions}

Drug-loaded microemulsions were prepared by adding $0.1 \%(\mathrm{w} / \mathrm{w})$ dexamethasone acetate to the microemulsion at room temperature. The mixture was gently shaken to ensure complete mixing and solubilization. The drug-containing microemulsion and solutions were shielded from light by storing in flasks wrapped with aluminum foil.

\section{HPLC assay of dexamethasone acetate in microemulsions}

For this assay, $1 \mathrm{~g}$ of microemulsion containing $0.1 \%$ $(\mathrm{w} / \mathrm{w})$ dexamethasone acetate was accurately weighed and dissolved in methanol, giving a solution of nominal concentration $15 \mu \mathrm{g} \cdot \mathrm{mL}^{-1}$. After that, the solution was filtered through a $0.22 \mu \mathrm{m}$ Millipore membrane filter and analyzed by HPLC. All determinations were conducted in triplicate.

\section{Method Validation}

The method was validated in accordance with International Conference on Harmonization guidelines ( $\mathrm{ICH}-$ 2003) for validation of analytical procedures

\section{Specificity and Selectivity}

These parameters were determined by comparing the chromatograms of the dexamethasone acetate standard, drug-loaded microemulsion and microemulsion without drug.

\section{Linearity}

The linearity was determined from the triplicate analytical curves obtained by HPLC analysis of dexamethasone acetate standard solutions.

\section{Accuracy}

The accuracy was determined by the standard addition method. Amounts of $5.0 ; 10.0 ; 15.0 \mu \mathrm{g} . \mathrm{mL}$ of the dexamethasone acetate standard were added to the microemulsions samples in which $10.0 \mu \mathrm{g} . \mathrm{mL}^{-1}$ of the drug had been incorporated previously. The final concentrations of the fortified solutions were 15.0,20.0 and $25.0 \mu \mathrm{g} . \mathrm{mL}^{-1}$ of dexamethasone. The recovery experiments were performed in triplicate for each concentration.

\section{Precision}

The precision of the assay was determined by repeatability (intra-day) and intermediate precision (inter-day). The intra-day precision was calculated as the relative standard deviation (RSD) of results from ten standard samples, during the same day, and the inter-day precision was studied by comparing the assays on two different days. Ten sample solutions $\left(15.0 \mu \mathrm{g} \cdot \mathrm{mL}^{-1}\right)$ were prepared and assayed, and the standard deviation (SD) and RSD were calculated.

\section{Limit of quantification}

The lower limit of quantification was the smallest analytical concentration which could be measured with precision and accuracy.

\section{RESULTS AND DISCUSSION}

In this study, a HPLC method for quantitative analysis of dexamethasone acetate in microemulsion was developed and validated.

\section{Specificity and Selectivity}

The specificity and selectivity describe the capacity 


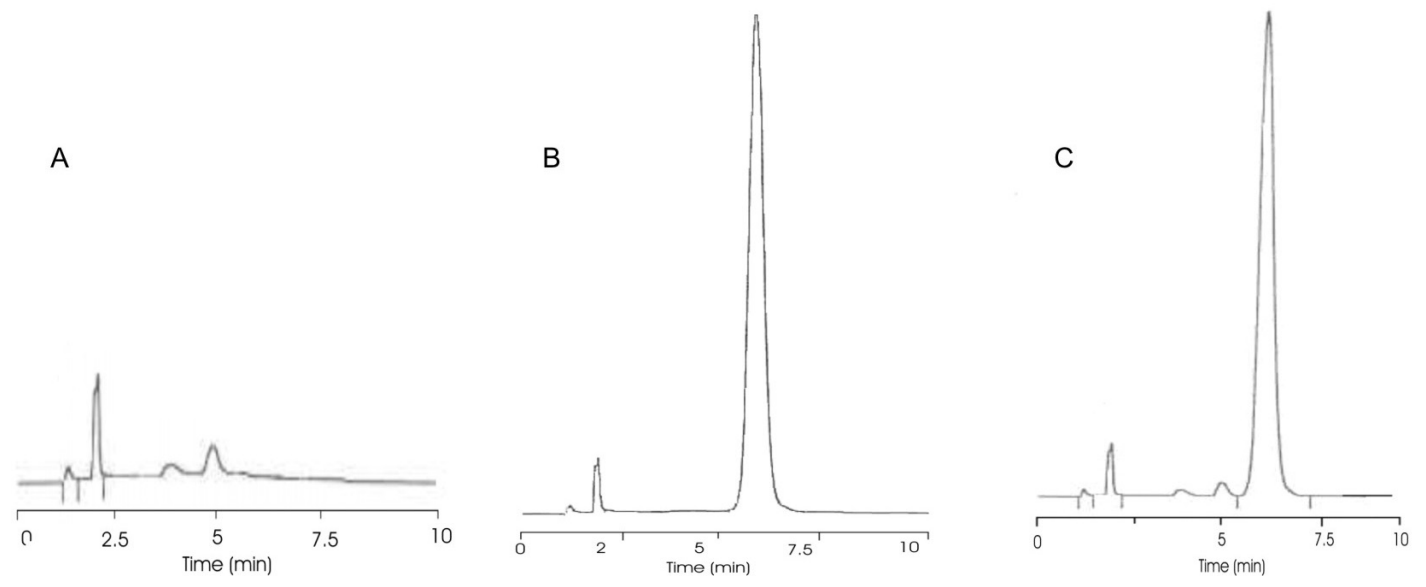

FIGURE 2 - HPLC chromatogram of (A) microemulsion, (B) dexamethasone acetate standard (20 $\left.\mu \mathrm{g} \cdot \mathrm{mL}^{-1}\right)$ and (C) dexamethasone acetate-loaded microemulsion $\left(20 \mu \mathrm{g} . \mathrm{mL}^{-1}\right.$ of drug). (Isocratic mobile phase of methanol:water $(65: 35 \mathrm{v} / \mathrm{v})$ flow rate at $1 \mathrm{~mL} \cdot \mathrm{min}^{-1}$, Lichrospher $100 \mathrm{RP}-18$ column at $30 \pm 2{ }^{\circ} \mathrm{C}$, UV detector at $239 \mathrm{~nm}$ )

of the analytical method to measure the drug in the presence of impurities, excipients, degradation products or matrix components (ICH, 2003; Brasil, 2003; USP, 2004). These parameters were determined by comparing the chromatograms of the dexamethasone acetate standard, drug-loaded microemulsion and microemulsion without drug.

The chromatogram of the dexamethasone acetate standard presented a peak in the time retention of 6.7 (Figure $2 \mathrm{~B}$ ). The chromatogram of dexamethasone-loaded microemulsion sample (Figure 2C) showed a peak and retention time similar to dexamethasone acetate standard (Figure 2B). The components of the microemulsion do not interfere with the analysis, therefore no peak is observed in the region of the main peak of dexamethasone (Figure 2A). The chromatogram peaks are well resolved, indicating the high specificity of the method. The retention time of $6.7 \mathrm{~min}$ is a good value for routine procedures in quality control. In fact, compared to values obtained elsewhere for analysis of dexamethasone acetate in creams $(8.5 \mathrm{~min}$ - Garcia et al., 2003) and ointments (11.7 min - Zivanovic et al., 2005), the present method proved advantageous, with a shorter retention time.

\section{Linearity}

The analytical curve for dexamethasone acetate standard was constructed by plotting the area under the curve (AUC) of the main peak versus drug concentration. It was found to be linear over a wide concentration range (2.0-30.0 $\left.\mu \mathrm{g} . \mathrm{mL}^{-1}\right)$ with a correlation coefficient of 0.9995 . The straight line equation obtained from the experimental results was found to be (Equation 3): $y=40456.425 x+6537.444$

The data were validated by analysis of variance, which demonstrated significative linear regression and non-significative deviation from linearity $(P<0.05)$. The RSD of the slope and of the intercept of the three lines were $1.95 \%$ and $2.9 \%$, respectively.

Thus, this HPLC method can be considered to show adequate linearity in the concentration range (2.0-30.0 $\left.\mu \mathrm{g} . \mathrm{mL}^{-1}\right)$ for quantitative analysis of dexamethasone acetate under the experimental conditions described.

\section{Accuracy}

Accuracy is one of the most important parameters of an analytical methodology and it can be expressed as the percent recovery of known amounts of drug added to a sample. The recoveries were determined by adding known amounts of the dexamethasone acetate reference substance $\left(5.0 \mu \mathrm{g} \cdot \mathrm{mL}^{-1}, 10.0 \mu \mathrm{g} \cdot \mathrm{mL}^{-1}\right.$ and $\left.15.0 \mu \mathrm{g} \cdot \mathrm{mL}^{-1}\right)$ to the microemulsion sample $\left(10.0 \mu \mathrm{g} \cdot \mathrm{mL}^{-1}\right)$. The results presented in Table I refer to the average of three assays

TABLE I - Analytical recovery of dexamethasone standard solution added to sample

\begin{tabular}{lcc}
\hline $\begin{array}{l}\text { Amount added } \\
\left(\mu \mathrm{g} \cdot \mathrm{mL}^{-1}\right)\end{array}$ & \multicolumn{2}{c}{ Recovery } \\
\cline { 2 - 3 } & $\mu \mathrm{g} \cdot \mathrm{mL}^{-1} \pm \mathrm{SD}$ & $\% \pm \mathrm{SD}$ \\
\hline 5.0 & $5.6 \pm 0.2$ & $112 \pm 1.3$ \\
10.0 & $11.2 \pm 1.2$ & $112 \pm 6.1$ \\
15.0 & $17.1 \pm 1.6$ & $114 \pm 6.5$ \\
\hline
\end{tabular}


TABLE II - Analysis of intra- and inter-day precision assays

\begin{tabular}{|c|c|c|c|c|}
\hline \multirow{3}{*}{$\begin{array}{l}\text { Theoretical concentration } \\
\left(\mu \mathrm{g} \cdot \mathrm{mL}^{-1}\right)\end{array}$} & \multicolumn{4}{|c|}{ Concentration } \\
\hline & \multicolumn{2}{|c|}{ Intra-day } & \multicolumn{2}{|c|}{ Inter-day } \\
\hline & $\mu \mathrm{g} \cdot \mathrm{mL}^{-1}$ & $\%$ & $\mu \mathrm{g} \cdot \mathrm{mL}^{-1}$ & $\%$ \\
\hline 15.00 & 15.5 & 103.7 & 15.2 & 101.5 \\
\hline 15.00 & 15.6 & 104.1 & 15.3 & 102.1 \\
\hline 15.00 & 15.3 & 102.1 & 15.3 & 102.3 \\
\hline 15.00 & 15.5 & 103.7 & 15.3 & 102.0 \\
\hline 15.00 & 15.3 & 102.3 & 15.3 & 101.9 \\
\hline 15.00 & 15.3 & 102.2 & 15.4 & 102.7 \\
\hline 15.00 & 15.2 & 101.6 & 15.4 & 102.4 \\
\hline 15.00 & 15.4 & 102.5 & 15.4 & 102.4 \\
\hline 15.00 & 15.2 & 101.5 & 15.4 & 103.0 \\
\hline 15.00 & 15.4 & 102.4 & 15.4 & 102.5 \\
\hline Average & 15.4 & & 15.3 & \\
\hline Standard Deviation $\left(\mu \mathrm{g} \cdot \mathrm{mL}^{-1}\right)$ & 0.14 & & 0.06 & \\
\hline Relative Standard Deviation (\%) & 0.88 & & 0.41 & \\
\hline
\end{tabular}

for each concentration. The results are in good agreement with acceptable values for the validation of an analytical procedure $($ recovery $=80-120 \%)($ Brittain, 1998; ANVISA, 2003).

\section{Precision}

The precision refers to the variability of the results in repeated analyses of the sample under identical experimental conditions. The method was validated by evaluating the intra- and inter-day precision. The precision was calculated from an average of ten determinations of a homogeneous sample (USP, 2004). The intra- and inter-day precision assays were expressed as relative standard deviation (RSD) 0.89 and 0.43 , respectively, indicating that the method presents a good precision (Brittain, 1998). The detailed precision data are shown at Table II.

\section{Limit of quantification}

The lower limit of quantification was determined to be $2 \mu \mathrm{g} \cdot \mathrm{mL}^{-1}$, with a relative standard deviation lower than $10 \%$.

\section{CONCLUSION}

The results show that the HPLC method presented here can be considered suitable for the analytical deter- mination of dexamethasone acetate in microemulsions, owing to its high selectivity and specificity, linearity in the concentration range used and high precision and adequate accuracy at the concentrations studied.

\section{ACKNOWLEDGEMENT}

The authors thank CAPES (Coordenação de Aperfeiçoamento de Pessoal de Nível Superior) and Rede Nanobiotech for their financial support.

\section{REFERENCES}

AVERY, M.A.; WOOLFREY, J.R. Antiinflamatory steroids. In: WOLFF, M.E. Burger's Medicinal Chemistry and Drug Discovery. 5.ed. New York: John Wiley \& Sons, 1997. cap.65, p.281-376.

BRASIL. Resolução RE n.899, de 29 de maio de 2003. A Agência Nacional de Vigilância Sanitária aprova guia para validação de métodos analíticos. Diário Oficial da União, Brasília, 2003b. Available at: $<\mathrm{http}: / / \mathrm{www}$.anvisa.gov.br $>$. Access on: April 15th. 2006.

BRITISH PHARMACOPOEIA. London: The Stationery Office, 2001. v.2, p.A437-A8.

BRITTAIN, H.G. Validação de métodos analíticos não cromatográficos. Pharm. Tech., v.6, p.4-9, 1998. 
CAPELLA-PEIRÓ, M.E.; GIL-AGUSTI, M.; MONFERRERPONS, L.; ESTEVE-ROMERO, J. Direct injection micellar liquid chromatographic method for the analysis of corticosteroids in creams, ointments and other pharmaceuticals. Anal. Chim. Acta., v.454, p.125-135, 2002.

CONSTANTINIDES, P.P.; SCALART, J.P. Formulation and physical characterization of water-in-oil microemulsions containing long- versus medium-chain glycerides. Int. J. Pharm., v.158, p.57-68, 1997.

FORMARIZ, T. P., URBAN, M. C. C., SILVA-JR, A. A., GREMIÃO, M. P. D., OLIVEIRA, A. G. Microemulsões e fase líquidas cristalinas como sistemas de liberação de fármacos. Revista Brasileira de Ciências Farmacêuticas, v.41, p.301-312, 2005.

GARCIA, C.V.; BREIER, A,R,; STEPPE, M.; SCHAPOVAL, E.E.; OPPE, T.P. Determination of dexamethasone acetate in cream by HPLC. J. Pharm. Biomed. Anal., v.31, p.597$600,2003$.

GASCO, M.R.; GALLARATE, M.; PATTARINO, F. On the release of prednisone from oil in water microemulsions. Farmaco, v.43, p. 325-350, 1988.

GUO, D.; CHEN, N.N.; YANG, X.X.; HOU, L.B. Determination of dexamethasone sodium phosphate content in fuyankang cream by high-performance capillary electrophoresis. $D i \mathrm{Yi}$ Jun Yi Da Xue Xue Bao, v.24, p.839-840, 2004.

HASHIGUSHI, T.; YASUTAKE, T.; MANAKO, T.; OTAGIRI, $M$. In vitro percutaneous absorption of prednisolone derivates based on solubility parameter. Int. J. Pharm., v.158, p.11-18, 1997.

\section{INTERNATIONAL CONFERENCE ON HARMONIZATION} (ICH); validation of analytical procedures: Methodology, Q2B (CPMP/ICH/281/95), 1995. Available at: <http://www. ich.org >. Access on: 30th. Aug. 2006.
KRZEK, J.; MASLANKA, A.; LIPNER, P. Identification and quantification of polymyxin $\mathrm{B}$, framycetin, and dexamethasone in an ointment by using thin-layer chromatographic with densitometry. J. AOAC Int., v.88, p.1549-1554, 2005.

LEHMANN, L.; KEIPERT, S.; GLOOR, M. Effects of microemulsion on the stratum corneum and hydrocortisone penetration. Eur. J. Pharm. Biopharm., v.52, p.129-136, 2001.

MILOJEVIC, Z.; AGBABA, D.; ERIC, S.; BOBERICBOROJEVIC, D.; RISTIC, P.; SOLUJIC, M. Highperformance liquid chromatographic method for the assay of dexamethasone and xylometazoline in nasal drops containing methyl p-hydroxybenzoate. J. Chromatogr. A., v. 949, p.79-82, 2002.

VIANNA, R.F.L.; BENTLEY, M.V.L.B.; RIBEIRO, G; CARVALHO, F.S.; NETO, A.F.; OLIVERIA, D.C.R.; COLLET, J.H. Formation of cyclodextrin inclusion complexes with corticosteroids: their characterization and stability. Int. J. Pharm., v.167, p.205-213, 1998.

WILLIAMS, P.; BIEHL, E.R. High-pressure liquid chromatographic determination of corticosteroids in topical pharmaceuticals. J. Pharma. Sci., v.70, p.530-534, 1981.

WU, F.; LV, J. Flow injection chemiluminescence detection and solvent extraction for human skin ointment dexamethasone acetate absorption analysis and the reaction mechanism study. Talanta, v.72, p.1811-1817, 2007.

ZIVANOVIC, L.; ZECEVIC, M.; MARKOVIC, S.; PETROVIC, S.; IVANOVIC, I. Validation of liquid chromatographic method for analysis of lidocaine hydrochloride, dexamethasone acetate, calcium dobesilate, butylhydroxyanisol and degradation product hydroquinone in suppositories and ointment. J. Chromatogr. A, v.1088, p.182-186, 2005.

Recebido para publicação em 23 de novembro de 2007. Aceito para publicação em 06 de outubro de 2008 